\title{
Museums: An institution for knowledge acquisition - A spotlight on the museum education in Ghana.
}

\author{
Kwasi Amoako - Ohene ${ }^{1}$, Nana Ama Pokua Arthur ${ }^{2}$, Samuel Nortey ${ }^{3}$ \\ 1P. O. Box KF 981, Koforidua Technical University, Koforidua.Email: amoakoohene3@gmail.com \\ ${ }^{2}$ Department of Educational Innovation in Science and Technology. KNUST, Kumasi \\ Email:napok.2601@gmail.com \\ ${ }^{3}$ Department of Industrial Art, KNUST, Kumasi \\ Email: sammynor@gmail.com
}

\begin{abstract}
Museums, just like formal institutions of learning always have understood that conserving collections for study and exhibition can be an important part of the educational process. Since 1957, Ghana has established several museums under the Museums and Monument Board. These museums just like others are required to play a great deal of role in the social, educational, economic development of a nation. However, it is distressing to note that with the highly endowed museum assets of Ghana, such as the Cape Coast Castle Museum, Ghana National Museum, Fort Appolonia Museum of Nzema History and Culture, the Elmina Castle Museum, Ho Museum, Bolga Museum, Wa Museum, The Head of State Museum and Museum of Science and Technology both in Accra, there has been little contributions to Ghana's Gross Domestic Product. Significantly, visitor experience and satisfaction is very low. In this view, this study sought to investigate educational activities of Ghana Museum and Monument Board (GMMB) and inquire into their educational activities. Employing qualitative approaches, the study used a triangulation of observations, interview and focus group discussion to assemble data from these museums. In conclusion, the museums provide some sort of education but there is no formalized educational framework serving as a guide. They mainly employ monotonous experience of guided and self-guided gallery tours, and occasionally, the museum curators and educators organize a oneoff programme such as an outreach to schools and special exhibitions as well as seminars. Recommendations to strengthening museum education in Ghana are addressed.
\end{abstract}

Keywords: museum education, , GMMB, visitor experience, exhibition, educational framework

Citation: Kwasi Amoako - Ohene, Nana Ama Pokua Arthur, and Samuel Nortey.Museums: An institution for knowledge acquisition - A spotlight on the museum education in Ghana, 20205 (2): 10-23.

Received: March 3, 2020

Accepted: June 30, 2020 


\subsection{Introduction}

Museums play a great deal of role in the social, educational and economic development of a nation. They provide a store of knowledge to the society and have been a bridge that provides understanding to the past, the present and the future. A society without the understanding of its cultural heritage would be without an identity. Ambrose and Paine (2006), posits that museums have a critical role to play in providing an appreciative of identity and a feeling of belonging to a place or society. According to the International Council of Museums (ICOM) (2001), museums are non-for-profit permanent institution in the service of society and of its development, that is made available to the public, to acquire, conserve, research, communicate and exhibit for purposes of study, education, enjoyment, material evidence of people and their environment. The educational mandates of museums are clearly evident in here.

It is obviously clear that museums are tasked to provide the society with education about their identity. Museums, be they art, history, or science museums, may be defined in the same way: they are permanent, public, educational institutions that offer organized care for collections (Burcaw ,1975). As stated by Bonner, 1985, museums likewise, institutions of formal learning always have understood that maintaining collections for study and exhibition can be an important part of the educational process.

In fulfilling their educational mandate, museums programmes and activities will have to be accepted by diverse audience as possible. It is therefore important to adopt strategies which focus on reducing challenges which prevent audience from visiting (Werner, 2003). In the case of individuals who have little interest in museums, hence visit these institutions only seldomly, it is perceived that their leisure time experiential preference is not fulfilled by museums but by other institutions which compete with museums.

Generally, learning in museums usually encompasses of a visitor or a group of visitors admiring an object on display and reading panels of narratives. (John, 1992). Trofanenko (2006) points out that, museums serve as a place where cultural ideas and creativity could, and should be interrogated. The experiences visitors gain are always useful ways of helping the individuals shape their preconceived perceptions since they now come face to face with realities of the collections.

According to American Association of Museums (2001), the various types of educational programmes generally undertaken by the museums include the following:

1. Textual representation of information during exhibitions gives clearer and further meanings to the collections. Text offers information which contributes to visitors' appreciation of a collection displayed. They should be an integral part of an exhibition. Visitors often use labels to tell each other about the subject and as a springboard for discussion between themselves.

2. Theatre Arts in the form of music and drama performances are ways of entertaining whiles studying. An instance is a case at the British Museum, where young people find ways of exploring with techniques in theatre arts presenting fascinating dramas with stories behind historical and contemporary objects from across the world and bringing those to life. It is the case that many museum objects do not have details of their histories represented therefore acting them out could bring an understanding to the visitors. Young people's creative responses and interpretation of these objects are as valid as anyone else's.

3. Another form of education in the museum is narration by museum guides to the various audiences on visit. Information is disseminated through question and answer sessions between the docent and the visitors.

4. Internships are also a form of educational activities. By this, students are given the opportunity to undertake a fulltime study of the operations of the museums and the training gathered helps them in their academic research. 
5. Fellowship opportunity is given by the museums to help scholars to acquire careers. Metropolitan Museum of Art for instance embraces applications from scholars of educational disciplines such as art history, archaeology, education, and conservation and related sciences, as well as from scholars in other fields whose projects are interdisciplinary in nature and relate to the objects. Astute Fellows form lifelong professional and personal relationships since they interrogate research questions, get critical on the museum objects, and they eventually share their experiences.

7. International Staff Exchange is also encouraged among various museums in different part of the world with different cultures and identity. Ideas from different backgrounds enhance knowledge sharing and this adds to the knowledge base of the individual museum staff and the individual visiting also benefit through knowledge acquired from the museum environment.

In Ghana, there are museums which are directly managed by chieftaincy such as Manhyia Palace Museum, Prempeh II Jubilee Museum all in Kumasi, the Ghana Armed Forces Museum by the military and a private museum also in Kumasi called The Hat Museum. The higher learning institutions also have such as the Museum of Archaeology at the University of Ghana, Aburi Botanical garden and Kakum National Park at Cape Coast are all examples of a 'living museums' in Ghana.

Furthermore, there are museums that fall under the Ghana Museum and Monument Board such as the Cape Coast Castle Museum, Ghana National Museum, Fort Appolonia Museum of Nzema Culture and History, Elmina Castle Museum, Ho Museum, Bolga Museum, Wa Museum, Museum of Science And Technology Museum in Accra, and lately added The Museum of Heads of State in Osu castle, Accra.It is distressing to note that with such museum assets, rich cultural and educational heritage these museums are contributing far less to the Gross Domestic Product of Ghana and significantly low visitor satisfaction experience. The usefulness of the role of museums in every nation needs much to be desired. If museums in Ghana become a strong educational institution, they could boost tourism and hence a great asset of cultural tourism products of the nation. Information from to the World Travel and Tourism Council (WTTC) reveals that the sector directly contributed GHS2.62bn (\$727m) to Ghana's GDP in 2013, or $3 \%$ of the total. This shoves the country above the global average of $2.9 \%$, but it trails behind regional leaders such as Gambia (9\%), Senegal (5.3\%) and Kenya (4.3\%). (Source: Oxford Business Group).

All the above museums if well-resourced to educate their audience properly will empower the museums as a vehicle for growth of the nation. This research therefore investigates the state of Museum Education provided by GMMB.

Evidence abounds that since independence, government appreciates the relevance of museums in nation building. The government appreciated the expediency to restore and conserve the past and therefore passed the Ghana Museums and Monuments Board ordinance and this established the GMMB. This organization is exclusively in charge of the protection and conservation of forts, castles and ancient merchant houses placed within the coastal belt, ancient traditional buildings like mosques and historic town walls located in the northern belt of the country.

Attracting visitors to museums are largely from the kind of strategies museums use to engage the visitors in the museum. Getting them to have memorable experience to enable them come back again and again and also inform others to visit do not only depend on the kind of collections a museum has but an appealing educational model. 


\subsection{Methodology}

The study employed a qualitative research approach in vividly describing the state of museums under GMMB and educational activities. In order to attain these objectives, extensive visits to these museums was done for 24 months. There was also visits to Smithsonian museums in the United State of America to study other museum educational frameworks that assist in satisfactory museum education. Using observations, interviews and focus group discussions, there were several interactions with the museum docents, curators and staff including the members of the Ghana Museum and Monument Board. The Focus Group Discussion assisted to explore and elicit expert input into how to strengthen museum education (Patton, 2005; Stewart and Shamdasani, 2014). The various exhibits of the museums were examined including how visitors to the museum are educated. This qualitative approach assisted the study to focus on the subjective information, such as perceptions, opinions and experiences of the visitors (Leedy and Ormrod, 2005). The study generally used plural approaches by combining different methods and sources which provided the potential to allow for fuller and more nuanced access to visitor understandings and experiences, as well as developed reflection on the ways in which the content of visitor expression may be examined

\subsection{Results and Discussions}

\subsection{The state of Museum Education provided by GMMB}

Museum education in Ghana is done largely by the use of the exhibits with few having provenances. It was observed that the docents and curators use exhibition styles, and gallery tour as forms of education. Comparatively, the strategic display technique and effective utilization of exhibition halls spaces which contribute to heightening museum experience was a bit of a challenge. Some of the museums do not have proper presentation of texts and panel narrations which essentially heightens the interpretation of the collections on display.

It is important to note that the strength of guided and unguided gallery tours lies in the presentation of the collections. The text and panels gives information that give the visitor a memorable experience. In some cases, the audio visuals added to the texts and exhibits better informs the visitor as shown on plate 1.

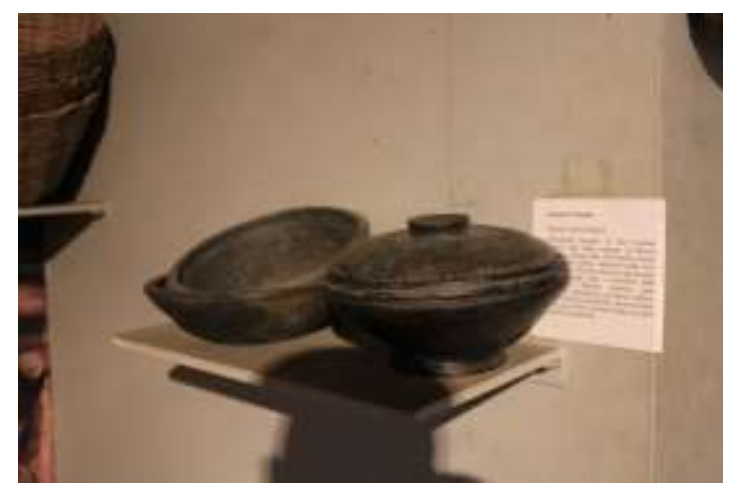

Plate 1: A collection with text at the Cape Coast Castle Museum Source: Fieldwork, 2019

A visitor to the museum always demands an expected experience which should be a lasting one. Customarily of a gallery tour, the visitor is caught engaged by the appearance of the display of the exhibits and the textual presentation and audio visuals which keeps the visitor in an enthusiastic mood and brings a lasting memory. According to Falk and Dierking (2000) visitors make a 'free-choice learning' as many museum visitors are repeat visitors knowing that there are personal pleasures, knowledge acquired and insightful reflections 
Even though good exhibition practice plays important role in museum education, it is ill-starred that some collections and their presentations are not in good condition. An example is seen on plate 2 in the Museum of the Fort St. Appolonia Museum of Nzema History and Culture.

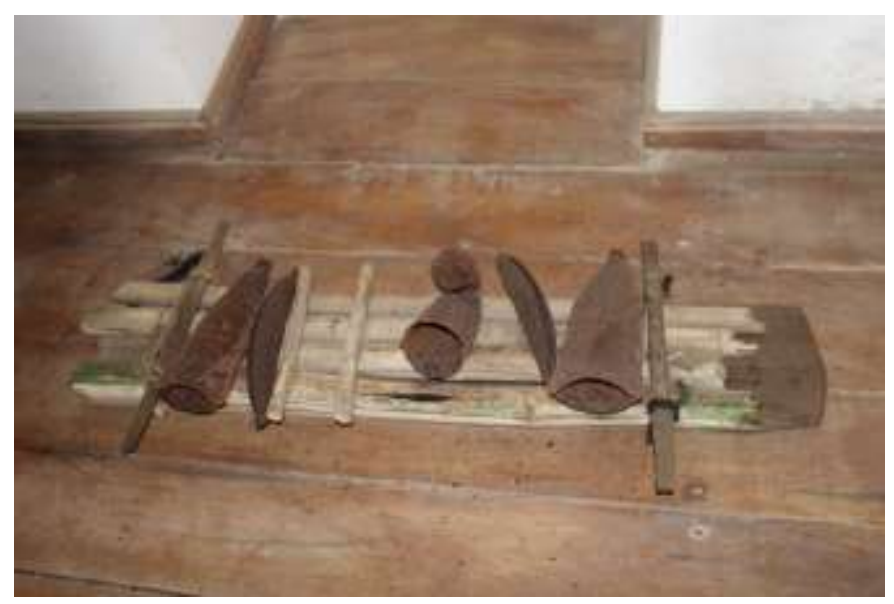

Plate 2: Rusted exhibits of gong-gongs and sticks

Source: Fieldwork, 2017

A visit to the Fort Appolonia Museum confirmed the deteriorating state of the exhibits. The once euphoric museum galleries have virtually become unkempt. The deplorable state could be due to lack of frequent maintenance to salvage the nuisance caused by the salty sea breeze be wilding the museum and its collection. The courtyard of the Fort Appolonia Museum was once used for performing arts activities. However, currently the whole building of the museum according to the museum educator seem neglected to deteriorate.

Interviews and interactions with the various museum workers such as directors, educators, conservators and curators at the various museums confirmed that the museums undertake similar activities. They mainly undertake guided and self-guided gallery tours. However, once in a long while some of them gather resources from various sources to come out with a programme. These periodic programmes vary from museum to museum. There are outreach programmes to schools or the museums host an art exhibition or organize seminars and art talks.

Outreach to schools are often done by the National Museum and the art exhibitions are done in the Museum of Science and Technology, all in Accra. The Upper East Regional Museum also organizes outreach programmes for junior and high school students. Below are some of the gallery tours and a display of exhibits at some of the GMMB museums:

\subsection{Self-guided Tours}

Self-guided or unguided gallery tour in the museum begins with an entry into the halls after a fee is paid at the entrance. The visitors are then ushered into the halls and usually given some instructions and a briefing or a summary of what the collections entails or the provenances. They then freely and independently explore the collections as they create their own meanings as seen in plate 3. They read the narratives on the panels with text beneath or besides the photographs or objects. A good exhibition styles helps the experience. A typical example is a visit to Cape Coast and Elmina Castle Museums. 
The tour could be done by individuals or a few at a time or groups of visitors. In any of the cases, with the help of the inscriptions and good exhibition styles, the visitors go through an experience peculiar to them.

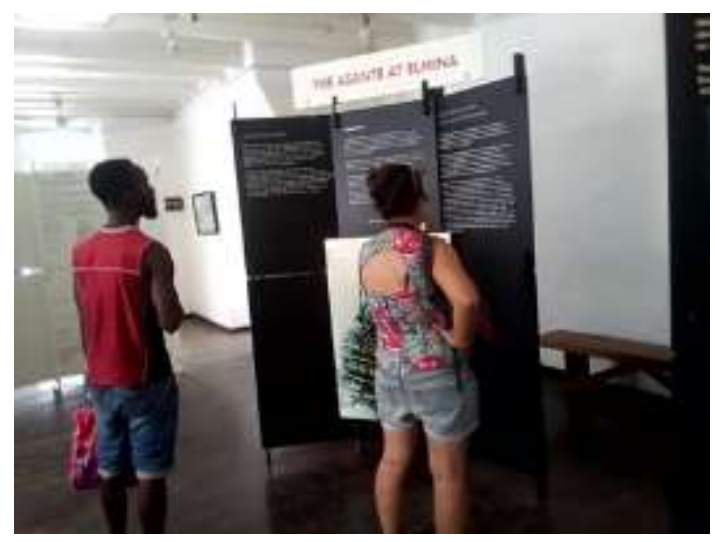

Plate 3: Visitors reading the narration of the exhibits Source: Fieldwork, 2017

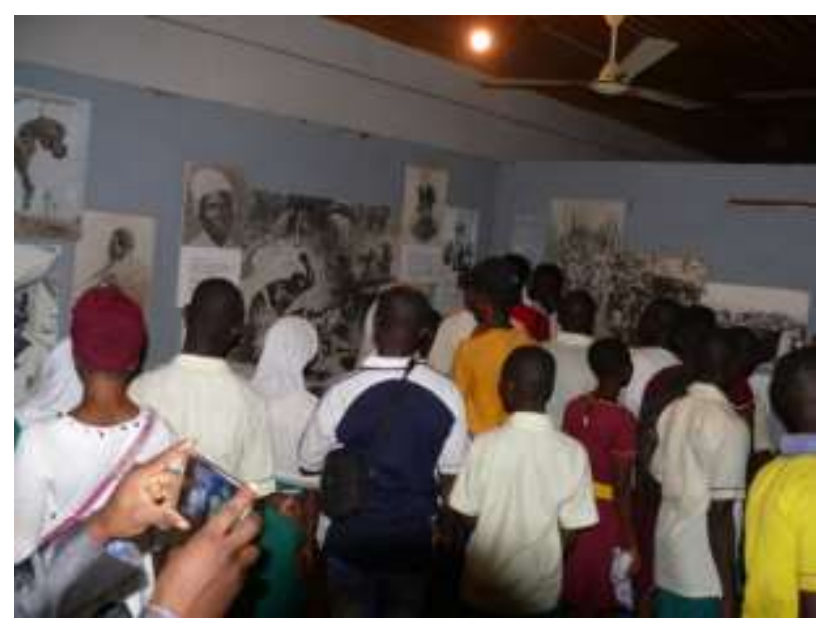

Plate 4: Group tour at the Cape Coast Museum

Source: Fieldwork, 2019

Sometimes due to the large number of visitors at a particular time, the visitors enjoy their visit in groups and have discussions on their own. In the occasion where individuals and smaller groups visit, they spend more time reading the panels and relating to stories with their experiences to make meanings. The exhibition has been well curated to give a clear meaning to the visitor. The content of the text is a narrative of the photograph and cultural description and artistic appreciation, all contribute to the education of the visitors.

Panels and textual presentations provide a great deal of education to the self-guided visitors. The texts beside or under a particular exhibit provide understanding devoid of any curator or educator's narrative. 


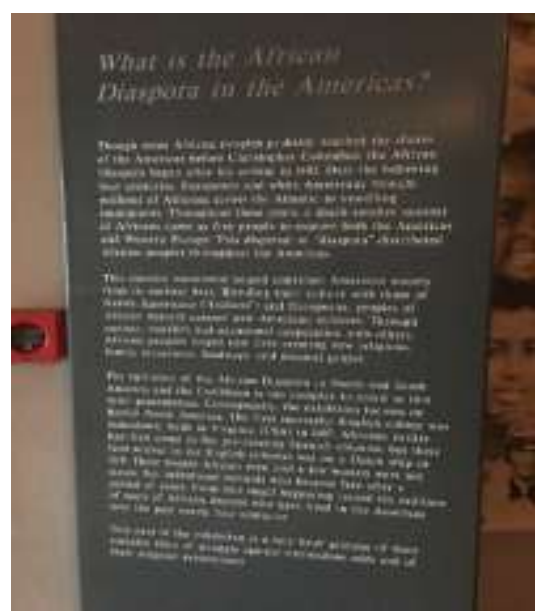

Plate 5: A panel providing education

Source: Fieldwork, 2019

\subsection{Guided gallery tours}

Guided tour is another major activity of the museums. The visitors are received by an educator, a docent or a volunteer and they are introduced to the gallery. The staff engages the visitors with a good customer service procedure.

The visitors are led through the displays while they go through certain routine thinking techniques however from observations they are engaged mainly with narratives and storytelling by the docents and the visitors occasionally put in a few questions for clarifications. The visitors are convened together in the case of large groups' tours. There are also cases where docents lead a few visitors of one to five to tour round. Although guided group tours are a major part of the museum audience, the vast majority of museum visits occur without human mediation (Worts, 2003). When the visitors are lead through the exhibits, there is certainly some sort of teaching occurs. Teaching here is conceptualized as the act of aiding visitors who lack knowledge and skills, understanding, or subject area by those who have them (Fenstermacher, 1986). The museum staff leading the tours through the exhibition and the galleries though time with the visitors is short live, generally measured in minutes and hours rather than days and months, there is evidence that the interactions are memorable (Anderson, et al., 2002).

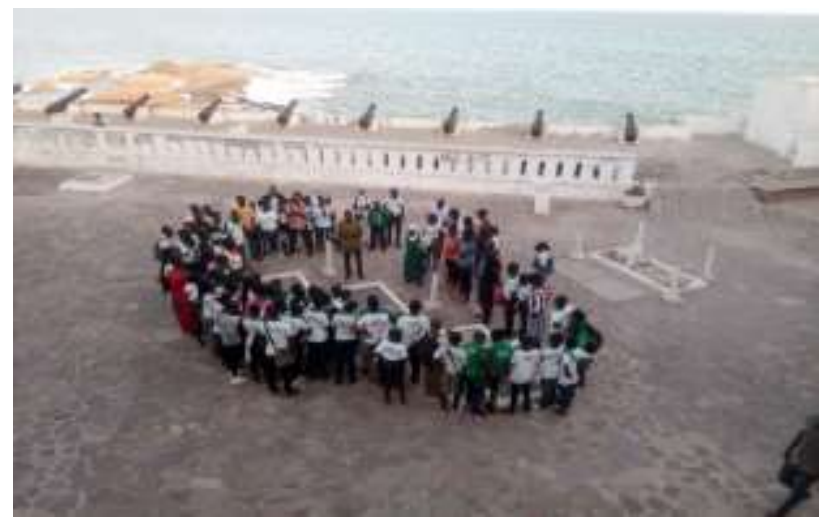

Plate 6: Visitors taking instructions before a guided tour at the Cape Coast Castle Museum

Source: Fieldwork, 2019 


\subsection{Children Outreach programmes undertaken by the National Museum}

Another form of educational activity undertaken by GMMB is an outreach programme by the National Museum. The Museum undertakes some outreach programmes to various basic schools in the Accra Metropolis. These outreach programmes provide opportunities for the children to discover their own identity, appreciate more cultural experiences and also understand historical involvements of their fore people and historical events such as the slave trade. In August 2017, at James Town Basic School, the children were taken through drawing, painting, puzzles, and also drama. This outreach was organized by Just Ghana; a non-governmental organization helping preserve Ghanaian cultural identity.

The programme was designed to introduce the children to museum education and were taught the importance of museums in nation building and the general reasons for establishing museums. They were encouraged to leisurely visit museums and hearten their parents to send them over for education and pleasure. The Educators took a time of storytelling narrating the slave trade and the involvement of the Ga people. The various activities which took place during the period of slavery and the various castles and forts used for the trade.

There were drama performances by the children. They acted the enslaved trade showing how the colonial masters connived with the local chiefs to sell slaves over to the foreigners in exchange of gunpowder, salt, whisky, etc. This was when they had heard the narration by the educator and they were guided to give a drama illustration of the painful history.

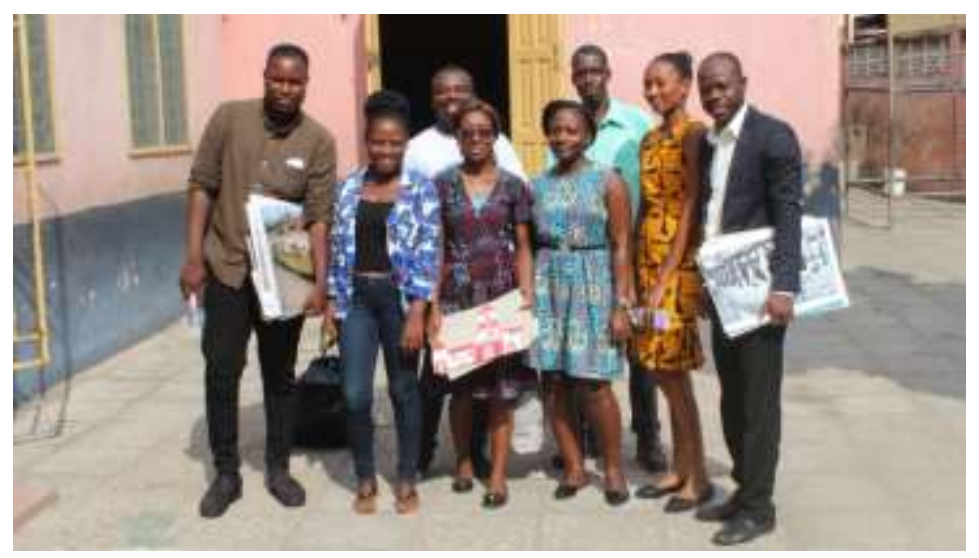

Plate 7: Docents, educators, resource persons after a focus group discussion

Source: Fieldwork, 2017 


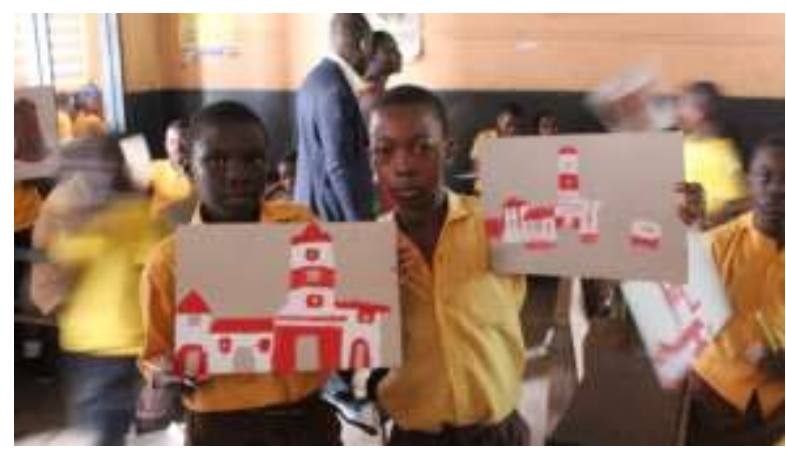

Plate 8: Drawings of castles by the children

Source: Fieldwork, 2017

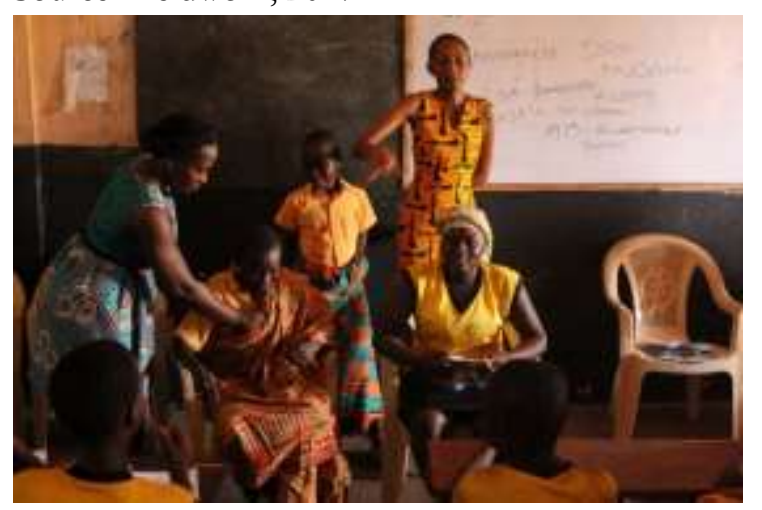

Plate 9: Drama by the children

Source: Fieldwork, 2017

At the end of the programme, the outcomes of the outreach were positive and joyful cultural and historical discoveries that encouraged the children to learn, practice and appreciate more cultural experiences.

Another outreach programme by the GMMB is the celebration of world Story Telling Day which is honoured globally on the $20^{\text {th }}$ of March each year. On this day as many relevant institutions as possible tell and listen to stories in as many languages and at many places as possible. Participants share and tell cultural stories and historical events. The Upper East Regional Museum in Bolgatanga takes advantage and hosts a programme dubbed 'Bolga Tells' each year.

In March 2019, the museum organized Bolga Tells, a programme which witnessed participants such as Mr. Ajene, Regional coordinating Director for Upper East chairing the occasion and the following dignitaries also in attendance: Regional Director of Ghana Library Authority, Regional Director of Centre for National Culture, representative from Zoom lion Bolga, Head of Department and Senior Lectures of Department of Industrial Art, Bolgatanga Polytechnic. And also, a representative from Bureau of National Investigative, staff of University of Ghana (Workers College) Bolga, Chief Executive of Narrative Changes and a representative from Ghana Tourism Authority.

The museum invited the following schools: Bolga Girls SHS (20 students), Zuarungu SHS (40 students) and 2 teachers) Zamse SHS (38 students) and Bethel Primary School (29 students and 3 teachers). Persons entreated the museum audience to stories about the history of the Bolga ethnic groups such as the Frafra and traditional folk tales amidst cultural drumming and dancing. Participants who excelled were giving awards. 


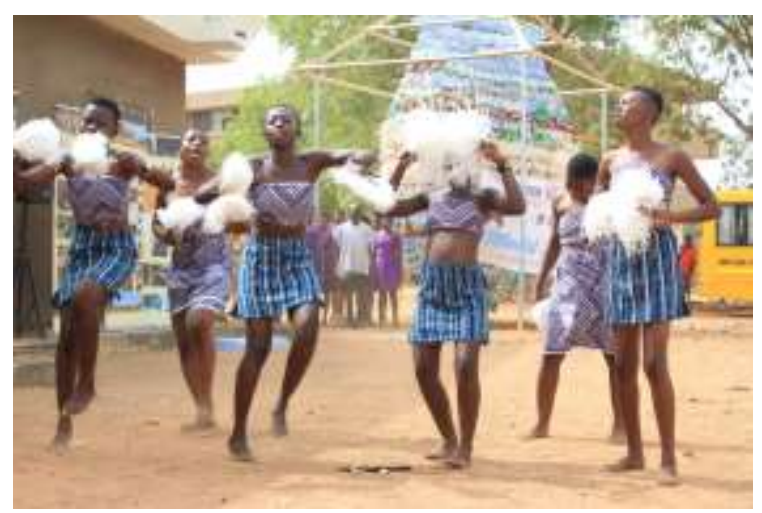

Plate 10: Cultural group of Zuarungu Senior High School Source: Fieldwork, 2019

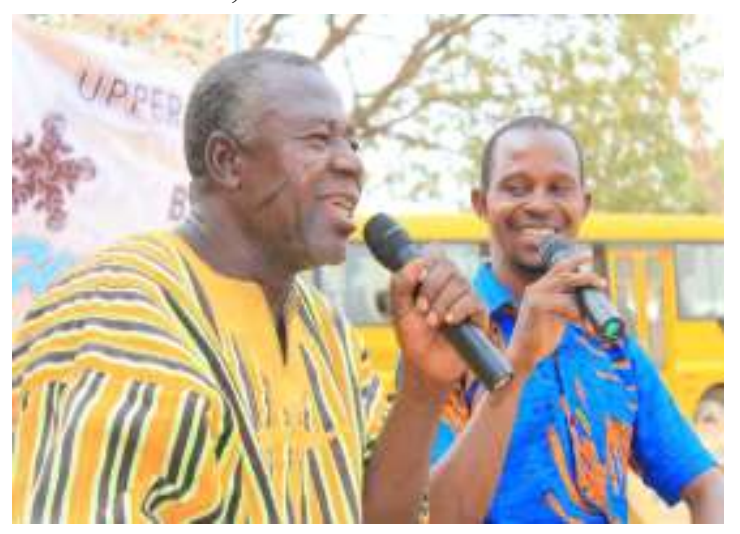

Plate 11: Story tellers

Source: Fieldwork, 2019

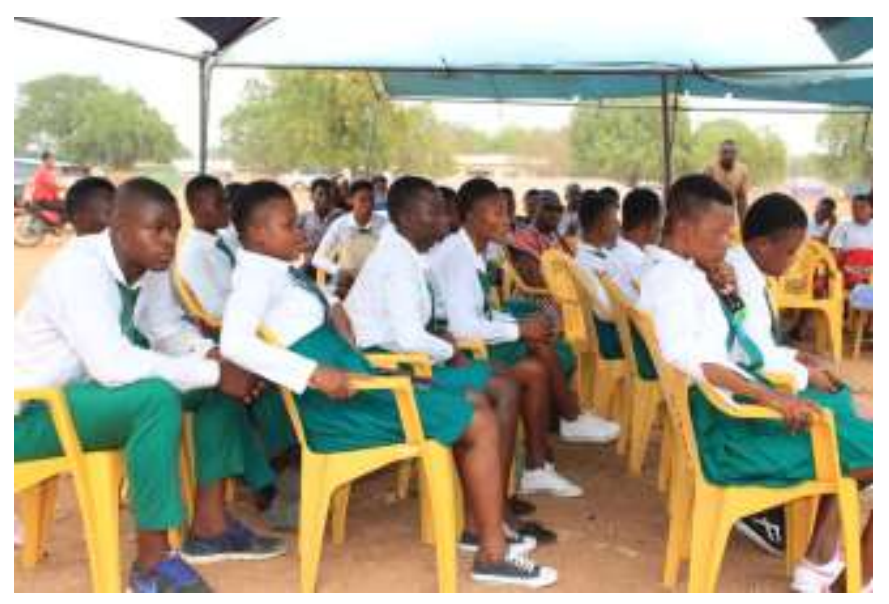

Plate 12: Students and teachers at the programs Source: Fieldwork, 2019 


\subsection{Special Exbibitions at Ghana Museum}

The museums organize special exhibitions once in a while. This complements the gallery exhibitions and gives special focus on particular subject matter. An example is a three-month long exhibition from January to March 2019 dubbed 'The exhibition on the architectural heritage of Ghana' held by the National Museum and also the exhibition by the University of Ghana and partners at the Heads of States Museum in Osu Castle as explained earlier.

The exhibition provided a sense of identity and continuity in the fast changing environment. The society is diluting the socio-cultural values of buildings and stories of their make-up which are either unknown or unexplored. The exhibition therefore sought to promote the identification, appreciation, research and documentation of historic building and intangible associates with them. It advanced the acknowledgement of architectural landscape as part of our narratives and the need to preserve them for posterity.

The exhibition identified different building and structures existing and non-existing in the country and explored their historic, social, and political and technological values. The exhibition was categorized into two sections which comprised the unfinished national museum building on the other hand and selected structures which emphasis civil, commercial religious, hospitality and residential buildings. (see plate 13).

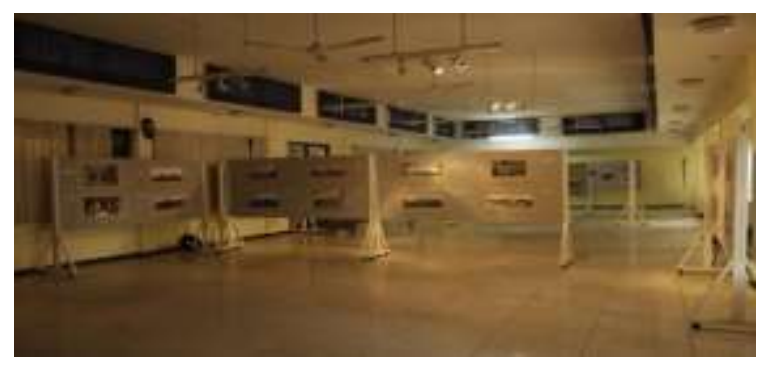

Plate 13: The exhibition at the education hall on the museum

Source: Fieldwork, 2019
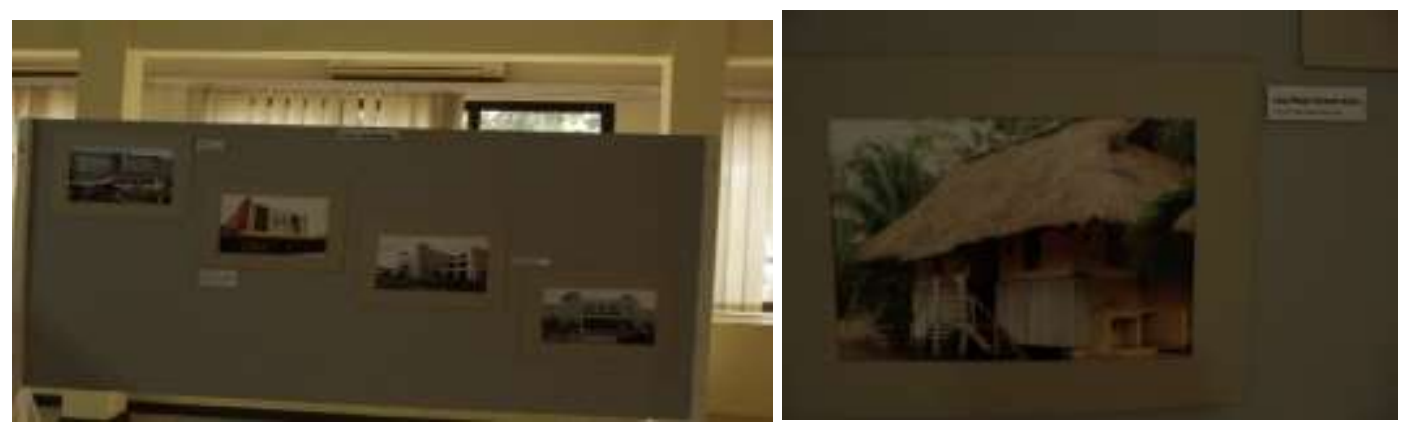

Plate 14: Photographs of civic building Source: Photographed by Amoako-Ohene

Plate 15: Photograph of Lou Moon Resort at Axim Source: Fieldwork, 2017

\subsection{Special exbibitions at MST}

Another special exhibition GMMB undertakes is one hosted in the Museum of Science and Technology (MST) in Accra by Kwame Nkrumah University of Science and Technology (KNUST) students. The Faculty of Art in KNUST in conjunction with the MST and blaxTARLINE Kumasi, put in a display of various contemporary artworks. This was last done in the year 2017. The exhibition was to honour the lifelong work of the Ghanaian modernist, Professor 
Ablade Glover, an internationally acclaimed painter and academician, who currently owns the Artists Alliance Gallery in Accra. This collaboration is accentuated by Goode (1995) and Seaver (1949) that cooperation between university faculties and museums as both share in the findings of research and exhibits. Indeed, exhibition is one sure way of receiving museum education.

The exhibition was opened by renowned Prof. El Anatsui, the Nigeria-based Ghanaian contemporary artist and alumnus of KNUST. The exhibition showcased works by a choice selection of artists from the 2017 graduating class as well as guest artists comprising alumni, teaching assistants and lecturers.

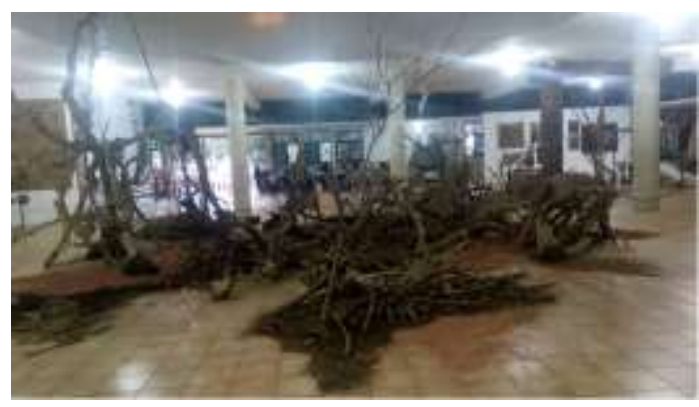

Plate 16: An installation by an Artist

Source: Courtesy of the artist

The exhibition had its theme as "Orderly Disorderly 2017" and it completes the trilogy of large-scale end-of-year exhibitions held by blaxTARLINES Kumasi, the contemporary art incubator space of KNUST, in collaboration with the GMMB and the Museum of Science and Technology (MST).

\subsection{Conclusion}

In summary, the various museums under the administration of the GMMB have been identified by their location in the country, the history of their establishment and the collections found in the museum. The various educational information in the museum have also been discussed.

In conclusion, the museums provide education but there is no formalized framework followed. Mainly monotonous experience of guided and self-guided gallery, there's virtually an absence of studies on the visitor experience of Ghanaian museum visitors to ascertain the facts about their experience and inquire about their preferences to the museums. The noticeable activities undertaken by the various museums are guided tours round the gallery with narratives and storytelling. Exhibition of collections with texts on panels with inscriptions of historical accounts with dates and brief description of exhibits.

Once in a long while, sometimes once in a year, the National Museum undertakes an outreach programme in Junior High Schools. This is carried out to educate the students about the importance of museums, heritage and identity on subjects in social studies (folklore about traditional heroes) and mathematics (study of shapes in the Kente cloth). There is also the world International Museum Day programmes. These include seminars, quizzes and art competitions for Senior High Schools. These together with world story telling day at the Bolga museum and special exhibition carried out by the National Museum and Museum of Science and Technology. These are sketchy ideas the museum curators and educators come together to undertake in Ghana. 


\subsection{Recommendation to the management of GMMB and policy makers}

The museum must align with academia for a collaborative effort to develop a framework of educational programmes and activities to be adopted as a policy for all the GMMB museums across the country to use.

We recommend that there should be much training given to the museum, docents, curators and educators on the framework in order to become acquainted with the in-an-outs of the various intricacies of the framework before applying.

The framework should be seen as a document to apply for funding. Museum funding all over the world has been a problem, all donors require judicious use of their fund to any institution. Therefore, the bulk of the framework could be broken down programme by programme and used to write for proposal for funding.

There should be regular collaboration between communities and museums. This would allow much audience participation. The state holders of the communities like, DCEs, chiefs and elders, assembly men, opinion leaders like doctors, headmasters, teachers, pastors and other professionals must be directory involved in the museum education. By so doing the museums would gain participation whiles the community is holistically and mutually beneficial to each other.

There should be museum and school collaboration right from basic to tertiary. Curriculum must include 'museum collection studies. The culture being practically taught in schools could be physically rehearse in the museum environment. Visits to museums must be made part of the prerequisite to graduate from one level of the academic ladder to the other.

Audience mobilization is key. It was found out that there was low patronage to the museum according to the survey. One way to get a lot more visitors is by way of introducing museum membership. The public could be asked to ask to register at various level of membership. Membership denotes your love for GMMB. Membership requires you to give to promote the wellbeing of the museum. However, the initial level is free, and the following are the levels and amount to give yearly. Member (free), Insider (GHS 50), Patron (GHS1000), Collector (GHS 3000), Connoisseur (GHS 10,000). By this, GMMB shall be in a way receiving funding for programmes whiles the visitors on the various levels receive preferential treatments depending on the level of membership they are and increase in patronage.

Recommended to the museum board is the need to get a journal. This would complement what is already being studied in the museum. The educators, curators and conservators shall be undertaking researches on collections and publish in this journal and by that education shall spread.

The museum board and management could undertake international exchange programs between museums for staff of the museum to equip them to be abreast with current trends of curating and education.

Internship and fellowship is a way to fuse academia with museum work. This is a way to formalize services to researchers and this could increase the museum knowledge bank. 


\section{References}

1. Ambrose, T. and Paine, C. (2006). Museum Basics. London: Routledge, p. 3.

2. American Association of Museums. (2007). AAM code of the ethics. Retrieved fromhttp://www.aamus.org/aboutaam/coe.cfm. accessed on 21st December, 2019.

3. Anderson, D., Piscitelli, B., Weier, K., Everett, M., \& Tayler, C. (2002). Children's museum experiences: Identifying powerful mediators of learning, Curator, 45 (3), 213-231.

4. Bonner, J. (1985). Museums in the classroom and the classrooms in the museum. Anthropology \& Education Quarterly, 16(4), 288-293.

5. Burcaw, G. (1975). Introduction to museum work. Nashville, TN: American Association for and State Local History.

6. Falk, J.H \& Dierking, L.D. (2000). Learning from museums: Visitor experiences and the making of meaning, Walnut Creek: Altamira

7. Fenstermacher, G.D. (1986). Philosophy of research on teaching: Three aspects in M.C Wittrock (Ed.), Handbook of research on teaching, $3^{\text {rd }}$ edition, New York: Macmillan, 37-49

8. Goode, G. (1995). The relationships and responsibilities of museums, Journal of Science, 2 (34), 197-209

9. Hein, G.E. (1998).Learning in the Museum. London: Routledge. http://archives.icom.museum/hist def eng.html,2001

10. Leedy, P.D \& Ormrod, J.E. (2005). Practical Research Planning and Design, $8^{\text {th }}$ Edition, New Jersey: Pearson Merril Prentice

11. Patton, M.Q. (2005). Qualitative evaluation and research methods, Thousand Oak: Sage

12. Seaver, E. (1949). The training of personnel in colleges and graduate schools for educational work in art museums, College Art Journal, 8(3), 182-187

13. Stewart, D.W. \& Shamdasani, P.N. (2014). Focus Groups: Theory and Practices, Newbury Park: Sage

14. Trofanenko, B. (2006). Interrupting the gaze: On reconsidering authority in the museum. Journal of Curriculum Studies, 38(1), 49 - 65.

15. Werner, T. (2003), "Entrepreneurship and marketing in audience development within New Zealand performing arts companies", Asia Pacific Journal of Arts and Cultural Management, Vol. 1 No.1, pp. 2234. (http:www.greekmythology.com).

16. Worts, D. (2003). On the brink of irrelevance: Art museum in contemporary society: In L. Tickle, V. Sekules and M. Xanthoudaki (Eds.), Opening up the cases: Visual arts education in the museums and galleries, Dordrecht: Kluwer, (pp. 215-31) 